\title{
POTENSI PENGEMBANGAN WISATA AIR DI WADUK JATIBARANG, SEMARANG BERBASIS NILAI EKONOMI
}

\author{
The Potency of Water Based Tourism Development in the Jatibarang Reservoir \\ (Semarang City) Based on Economic Value \\ Adam Bergas Prayuda, Frida Purwanti*) dan Dian Wijayanto \\ Progam Studi Manajemen Sumberdaya Perairan, Departemen Sumberdaya Akuatik \\ Fakultas Perikanan dan Ilmu Kelautan, Universitas Diponegoro \\ J1. Prof. Soedarto, SH, Tembalang, Semarang, Jawa Tengah - 50275, Telp/Fax, +6224 7474698 \\ Email : adambergas@gmail.com
}

\begin{abstract}
ABSTRAK
Penelitian ini bertujuan untuk mengetahui potensi pengembangan wisata air di waduk Jatibarang dengan menghitung nilai ekonomi Objek Wisata Waduk menggunakan Travel Cost Method (TCM), Willingnes to Pay (WTP), Net Benefit dan $R / C$ Ratio. Penelitian ini juga melihat persepsi responden tentang potensi tersebut. Jumlah responden dalam penelitian ini adalah 100 orang dan 6 orang pelaku usaha di lokasi wisata. Teknik pengambilan data menggunakan teknik Convenience Sampling. Hasil penelitian menunjukkan kondisi fisik Objek Wisata Waduk Jatibarang dalam kategori baik sedangkan aksesibilitas dan fasilitas dalam kategori kurang baik. Pengembangan Objek Wisata Waduk Jatibarang lebih mengacu pada peningkatan kepuasan dan kenyamanan, keindahan alam tetap dijaga dan opsi penambahan wisata. Wahana wisata yang ada di objek wisata yaitu speed boat dan perahu motor. Opsi penambahan wahana wisata terdiri dari becak air, perahu dayung, wisata kuda, mandi bola, banana boat dan wake board. Pengembangan wisata waduk dengan penambahan wahana wisata yang sesuai dengan estimasi pengguna tertinggi adalah becak air, dengan nilai Willingnes to Pay (WTP) adalah Rp. 10.000,00 dan nilai Net Benefit sebesar Rp. 115.829.100,00. Nilai ekonomi objek Wisata Waduk Jatibarang Semarang dengan menggunakan Travel Cost Method (TCM) sebesar Rp. 215.241.445,00/ tahun. Nilai R/C Ratio waduk sebesar 0,066.
\end{abstract}

Kata kunci : Waduk Jatibarang; Wisata Air; Travel Cost Method (TCM); Willingnes to Pay

(WTP); Net Benefit; R/C Ratio

\begin{abstract}
The research aim to know the potency of water tourism development by calculating economic value in the Jatibarang Reservoir using Travel Cost Method (TCM), Willingnes to Pay (WTP), Net Benefit and R/C Ratio as well as to know respondent perception on this potency of reservoir tourism development. Respondent of the research were 100 people and 6 businesses men. Data collected using convenience sampling technique. The research showed that physical condition of tourism attractions is good, whereas accesibility and facilities are not good. Attractions of the Jatibarang Reservoir development refers to increasing satisfaction and comfort, maintaining of nature and option for adding tourist attraction. Rides tourist attractions are speed boats and motorboats. Extra options of tourism attraction include water tricycles, paddle boats, horseback tours, bath balls, banana boat and wake board. The highest estimated option of tourism development is water tricycles, with willingnes to Pay (WTP) value about IDR. 10,000.00 and Net Benefit value about IDR. 115,829,100.00. The economic value of the Jatibarang Reservoir Semarang by the Travel Cost Method (TCM) is IDR. 215,241,445.00 / year. Reservoir R/C Ratio value about 0.066
\end{abstract}

Keywords : Jatibarang Reservoir; Water Based Tourism; Travel Cost Method (TCM); Willingnes to Pay (WTP); Net Benefit; R/C Ratio

*) Penulis penanggung jawab

\section{PENDAHULUAN}

Kota Semarang adalah Ibu Kota Propinsi Jawa Tengah yang terletak pada lokasi yang strategis, baik secara tatanan regional maupun sub regional dan merupakan titik simpul atau transit point regional sehingga menjadikan Kota Semarang terus berkembang. Pemerintah Kota Semarang telah menetapkan satu paket agenda kegiatan yang menjadi prioritas saat ini antara lain mengatasi banjir, memperbaiki sistem drainase Kota Semarang dan meningkatkan pengadaan air minum warga Kota Semarang atau lebih spesifiknya yaitu normalisasi Kali Garang atau Banjir Kanal Barat dan pengelolaan Waduk Jatibarang.

Wisata Waduk Jatibarang adalah pengembangan dari objek wisata Goa Kreo yang mampu menghidupkan kembali keinginan masyarakat untuk berwisata. Adanya fasilitas becak air, jet ski, memancing serta kuliner mampu menghidupkan potensi wisata di Waduk Jatibarang sendiri. Pertumbuhan wisatawan di hari biasa, maupun akhir pekan, 
serta hari-hari besar sangat mendorong kemajuan potensi wisata di daerah tersebut. Dampak pembangunan Waduk Jatibarang juga sangat dirasakan oleh Objek Wisata Goa Kreo, wisatawan yang berkunjung di hari biasa meningkat 10\%-20\% sedangkan di akhir pekan dan hari besar meningkat hingga 40\%. (BPS Kota Semarang, 2015)

Penelitian ini bertujuan untuk mengetahui potensi pengembangan wisata air di waduk Jatibarang dengan menghitung nilai ekonomi Objek Wisata Waduk menggunakan Travel Cost Method (TCM), Willingnes to Pay (WTP), Net Benefit dan R/C Ratio. Menurut Siregar (2010), Metode biaya perjalanan bertujuan untuk mengetahui nilai ekonomi objek wisata alam dengan cara menghitung sejumlah biaya yang dikeluarkan oleh pengunjung mulai dari tempat tinggal, selama perjalanan sampai di daerah objek wisata itu sendiri dari kembali lagi ke tempat tinggalnya. Besarnya intensitas kunjungan serta faktor-faktor yang mempengaruhi intensitas kunjungan tersebut perlu diketahui sebagai bahan pertimbangan bagi pengelolaan yang lebih baik di masa datang.

\section{MATERI DAN METODE PENELITIAN \\ Waktu dan Tempat}

Penelitian dilaksanakan pada bulan Agustus-September 2016 di Waduk Jatibarang Semarang, analisis data dan penyusunan laporan dilakukan di Kampus Universitas Diponegoro Semarang

\section{Teknik Pengambilan Sampel}

Teknik Pengambilan sampel yang digunakan yaitu Convenience Sampling dengan responden ditentukan berdasarkan pengunjung yang datang dan menikmati fasilitas yang ada di objek penelitian serta relevan terhadap kondisi sebenarnya (Sugiyarto et.,al, 2001). Penentuan jumlah sampel menggunakan rumus Slovin, yaitu

$$
\mathrm{n}=\frac{\mathrm{N}}{1+\mathrm{N}(\mathrm{e})^{2}}=\frac{134.685}{1+134.685(0,1)^{2}}=\frac{134.685}{1347,85}=99,926=100
$$

Keterangan :

$$
\begin{array}{ll}
\mathrm{N} & =\text { Ukuran sampel yang dibutuhkan } \\
\mathrm{N} & =\text { Ukuran populasinya } \\
\mathrm{E} & =\text { Margin error yang diperkenankan 0,1 (Kusmayadi dan Sugiyarto dalam } \\
& \text { Siregar, 2010). }
\end{array}
$$

\section{Teknik Pengumpulan Data}

Data dikumpulkan dari sumber Data Primer dan Data Sekunder. Data primer dikumpulkan melalui teknik wawancara langsung dan observasi terhadap responden yang ada di lapangan. Informasi yang dikelompokkanmeliputi :(1) Data karakterisitik pengunjung (nama, jenis kelamin, umur, pendidikan terakhir, pekerjaan, tempat tinggal, lama perjalanan, banyaknya kunjungan, kendaraan yang digunakan, kenyamanan objek wisata, kepuasan, keamanan, keindahan alam, tujuan utama kunjungan), (2) Data untuk menentukan nilai ekonomi objek wisata dengan menggunakan metode biaya perjalanan (biaya transportasi, biaya tiket masuk, biaya konsumsi yang dikeluarkan selama kegiatan wisata, biaya pembelian souvenir, biaya wahana wisata dan biaya lain yang telah dikeluarkan pengunjung untuk kegiatan wisata).

Data Sekunder merupakan data yang dikumpulkandari studi pustaka atau sumber lain yang terkait meliputi : letak geografis dan batas wilayah daerah objek wisata, iklim (suhu, musim, angin dan curah hujan), data kependudukan dan sosial ekonomi masyarakat serta jumlah total pengunjung pada tahun sebelumnya, investasi pembangunan waduk, lama pembangunan waduk, umur proyek waduk, biaya operasional per tahun selama pembangunan waduk.

\section{Teknik Pengolahan dan Analisa Data}

\section{Pendugaan Nilai dan Manfaat Rekreasi Metode Biaya Perjalanan (Travel Cost Method)}

Besarnya biaya perjalanan rata-rata dari jumlah total biaya perjalanan yang dikeluarkan selama melakukan perjalanan rekreasi, ditentukan menurut (Sulistiyono, 2007) :

$$
\mathrm{BP}=\mathrm{BT}+\mathrm{BK}+\mathrm{BTk}+\mathrm{BW}+\mathrm{BL}
$$

\section{Keterangan:}

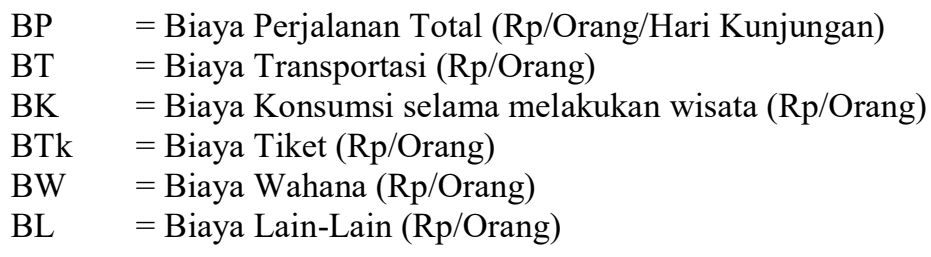




\section{Persepsi Wisatawan Tentang Pengembangan Objek Wisata \\ Meningkatkan Kenyamanan} berikut :

Tingkat kenyamanan pengunjung secara matematis menurut (Pramudhito, 2010), dapat dirumuskan sebagai

$\mathrm{NN}=\frac{\mathrm{Rb}}{\mathrm{Sr}} \mathrm{x} 100 \%$

Keterangan :

$\mathrm{NN} \quad=$ Nilai kenyamanan dalam persen

$\mathrm{Rb} \quad=$ Jumlah responden yang menyatakan Sangat Setuju dan Setuju

$\mathrm{Sr} \quad=$ Jumlah seluruh responden

\section{Menjaga Keindahan Alam}

Tingkat keindahan alam menurut pengunjung secara matematis menurut (Pramudhito, 2010), dapat dirumuskan sebagai berikut :

$\mathrm{NI}=\frac{\mathrm{Rb}}{\mathrm{Sr}} \times 100 \%$

\section{Keterangan :}

$\mathrm{NI} \quad=$ Nilai keindahan dalam persen

$\mathrm{Rb} \quad=$ Jumlah responden yang menyatakan Sangat Setuju dan Setuju

$\mathrm{Sr}=$ Jumlah seluruh responden

\section{Meningkatkan Kepuasan} berikut :

Tingkat kepuasan pengunjung secara matematis menurut (Pramudhito, 2010), dapat dirumuskan sebagai $\mathrm{NP}=\frac{\mathrm{Rb}}{\mathrm{Sr}} \mathrm{x} 100 \%$

\section{Keterangan :}

NP $=$ Nilai kepuasan dalam persen

$\mathrm{Rb} \quad=$ Jumlah responden yang menyatakan Sangat Setuju dan Setuju

$\mathrm{Sr}=$ Jumlah seluruh responden

\section{Nilai Keuntungan (Net Benefit)}

Net benefit digunakan untuk mengetahui nilai keuntungan usaha yang ada maupun untuk rencana penambahan usaha. Menurut (Commonet al., 1998), berikut adalah rumus dari Net Benefit :

$$
\mathrm{NB}=\mathrm{B}-\mathrm{C}
$$

Keterangan :

$$
\begin{aligned}
& \text { NB } \quad=\text { Net Benefit } \\
& \mathrm{B}=\text { Benefit } \\
& \mathrm{C}=\text { Cost }
\end{aligned}
$$

\section{Analisa Laba dan Rugi}

Biaya, penerimaan dan keuntungan $R / C$ ratio digunakan untuk menganalisa kelayakan usaha. Secara Matematis dapat dirumuskan sebagai berikut :

$R / C$ Ratio $=\frac{\text { Total Penerimaan }}{\text { Total Biaya }}$

Analisis kelayakan dari $R / C$ Ratio adalah :

$\mathrm{R} / \mathrm{C}>1=$ usaha layak atau untung

$\mathrm{R} / \mathrm{C}=1=$ usaha impas

$\mathrm{R} / \mathrm{C}<1=$ usaha tidak layak atau rugi. 


\section{HASIL DAN PEMBAHASAN}

Persepsi Kondisi Objek Wisata

Penilaian responden terhadap kondisi objek wisata dapat dilihat pada Tabel 1

Tabel 1. Persepsi Responden Terhadap Kondisi Objek Wisata (\%)

\begin{tabular}{lccccc}
\multicolumn{1}{c}{ Indikator } & $\mathbf{1}$ & $\mathbf{2}$ & $\mathbf{3}$ & $\mathbf{4}$ & $\mathbf{5}$ \\
\hline Kondisi Fisik Waduk & 0 & 81 & 19 & 0 & 0 \\
Aksesibilitas & 0 & 3 & 21 & 76 & 0 \\
Fasilitas & 0 & 14 & 6 & 80 & 0 \\
\hline
\end{tabular}

Keterangan : 1. Sangat Baik, 2. Baik, 3. Netral, 4. Tidak Baik, 5. Sangat Tidak Baik

Mayoritas responden menyatakan kondisi objek wisata dalam keadaan baik pada kondisi fisik waduk, sedangkan fasilitas dan aksesibilitas dalam keadaan tidak baik. Kondisi tersebut sesuai dengan pendapat Suwantoro (2002), mengatakan bahwa pembangunan sarana wisata yang mempertimbangkan kondisi dan lokasi akan meningkatkan akses menuju objek wisata tersebut yang nantinya akan menguntungkan objek wisata itu sendiri.

\section{Persepsi Fasilitas Objek Wisata}

Penilaian responden terhadap fasilitas objek wisata dapat dilihat pada Tabel 2

Tabel 2. Persepsi Responden Terhadap Fasilitas Objek Wisata (\%)

\begin{tabular}{|c|c|c|c|c|c|}
\hline Indikator & 1 & 2 & 3 & 4 & 5 \\
\hline Loket Tiket & 0 & 2 & 21 & 77 & 0 \\
\hline Area Parkir & 0 & 26 & 9 & 65 & 0 \\
\hline Toilet & 0 & 12 & 12 & 76 & 0 \\
\hline Tempat Ibadah & 0 & 2 & 19 & 79 & 0 \\
\hline Keamanan & 0 & 56 & 2 & 42 & 0 \\
\hline Tempat Duduk & 0 & 0 & 10 & 90 & 0 \\
\hline Tempat Sampah & 0 & 1 & 21 & 78 & 0 \\
\hline Kios / Warung Makan & 0 & 75 & 25 & 0 & 0 \\
\hline
\end{tabular}

Keterangan : 1. Sangat Baik, 2. Baik, 3. Netral, 4. Tidak Baik 5. Sangat Tidak Baik

Mayoritas responden menyatakan kondisi fasilitas objek wisata dalam keadaan tidak baik kecuali pada kios atau warung makan dan keamanan.

\section{Persepsi Daya Tarik Objek Wisata}

Penilaian responden terhadap daya tarik objek wisata dapat dilihat pada Tabel 3

Tabel 3. Persepsi Responden Terhadap Daya Tarik Objek Wisata (\%)

\begin{tabular}{|c|c|c|c|c|c|}
\hline Indikator & 1 & 2 & 3 & 4 & 5 \\
\hline Speed Boat & 3 & 84 & 13 & 0 & 0 \\
\hline Perahu Motor & 4 & 81 & 10 & 5 & 0 \\
\hline Kuliner & 0 & 70 & 30 & 0 & 0 \\
\hline Memancing & 23 & 63 & 4 & 10 & 0 \\
\hline Pemandangan Alam & 2 & 80 & 18 & 0 & 0 \\
\hline
\end{tabular}

Keterangan : 1. Sangat Menarik, 2. Menarik, 3. Netral, 4. Tidak Menarik 5. Sangat Tidak Menarik

Mayoritas responden menyatakan daya tarik wisata di Objek Wisata Waduk Jatibarang dalam kondisi baik, perpaduan antara daya tarik yang alami dengan buatan mampu menarik minat pengunjung untuk berwisata. 


\section{Persepsi tentang Pengembangan Objek Wisata}

Penilaian terhadap pengembangan objek wisata dapat dilihat pada Tabel 4

Tabel 4. Persepsi Responden tentang Pengembangan Objek Wisata (\%)

\begin{tabular}{lccccc}
\hline \multicolumn{1}{c}{ Indikator } & $\mathbf{1}$ & $\mathbf{2}$ & $\mathbf{3}$ & $\mathbf{4}$ & $\mathbf{5}$ \\
\hline Meningkatkan Kepuasan & 17 & 59 & 24 & 0 & 0 \\
Menjaga Keindahan Alam & 0 & 75 & 24 & 1 & 0 \\
Meningkatkan Kenyamanan & 0 & 68 & 31 & 1 & 0 \\
Keinginan Untuk Kembali & 8 & 69 & 23 & 0 & 0 \\
Opsi Penambahan Wahana Wisata & 6 & 87 & 7 & 0 & 0 \\
\hline
\end{tabular}

Keterangan : 1. Sangat Setuju, 2. Setuju, 3. Netral, 4. Tidak Setuju, 5. Sangat Tidak Setuju

Tingkat kepuasan di objek wisata memiliki nilai (skor) $76 \%$. Nilai (skor) kepuasan yang merupakan akumulasi dari tingkat kepuasan sangat setuju dan setuju. Nilai (skor) tersebut menunjukkan bahwa tingkat kepuasaan dalam kesesuian wisata yang baik. Tingkat keindahan alam di objek wisata memiliki nilai (skor) $75 \%$. Nilai (skor) dari keindahan alam yang merupakan akumulasi dari tingkat keindahan alam sangat setuju dan setuju adalah $75 \%$. Nilai (skor) tersebut menunjukkan bahwa tingkat keindahan alam dalam kesesuian wisata yang baik. Tingkat kenyamanan di objek wisata memiliki nilai (skor) $68 \%$. Nilai (skor) dari tingkat kenyamanan yang merupakan akumulasi dari tingkat kenyamanan sangat setuju dan setuju. Nilai (skor) tersebut menunjukkan bahwa tingkat kenyamanan dalam kesesuian wisata yang baik.

\section{Analisa Travel Cost Method (TCM)}

Biaya yang dimaksud dalam metode ini adalah dari biaya transportasi yang dikeluarkan pengunjung untuk pergi ke lokasi wisata, biaya konsumsi yang dikeluarkan selama perjalanan dan di objek wisata, biaya wahana wisata, biaya souvenir, biaya lain-lain (seperti toilet dan membeli pakan umpan untuk memancing)

Besarnya total biaya perjalanan rata-rata yang dikeluarkan satu orang pengunjung dari seluruh daerah adalah sebesar Rp. 127.269,00. Nilai biaya perjalanan tertinggi berasal dari daerah Semarang Timur yaitu sebesar Rp.1.793.000,00 dengan rata-rata biaya Rp. 119.533,00, sedangkan nilai biaya perjalanan terendah berasal dari daerah Ungaran yang terletak cukup jauh dari objek wisata ini yaitu sebesar Rp. $50.000,00$ dengan rata-rata biaya Rp.50.000,00.

Tabel 5. Rekapitulasi Data Responden Berdasarkan Rata-Rata Biaya Perjalanan

\begin{tabular}{|c|c|c|c|c|c|c|c|c|c|}
\hline No. & Daerah/ Regional/ Kota & Jumlah Responden & Transportasi & Wahana Wisata & Souvenir & Konsumsi & Lain-lain & Rata-Rata Biaya & Biaya Perjalanan \\
\hline 1 & Gunung Pati & 8 & 258.400 & 135.000 & 0 & 170.500 & 16.000 & 72.488 & 579.900 \\
\hline 2 & Semarang Tengah & 11 & 505.000 & 350.000 & 50.000 & 232.500 & 15.000 & 104.773 & 1.152 .500 \\
\hline 3 & Semarang Utara & 8 & 170.000 & 110.000 & 25.000 & 235.000 & 13.000 & 69.125 & 553.000 \\
\hline 4 & Semarang Timur & 15 & 775.000 & 385.000 & 175.000 & 450.000 & 8.000 & 119.533 & 1.793 .000 \\
\hline 5 & Semarang Barat & 8 & 160.000 & 120.000 & 0 & 160.000 & 6.000 & 55.750 & 446.000 \\
\hline 6 & Semarang Selatan & 12 & 350.400 & 85.000 & 70.000 & 295.000 & 15.000 & 67.950 & 815.400 \\
\hline 7 & Mijen & 3 & 29.000 & 0 & 10.000 & 52.000 & 5.000 & 32.000 & 96.000 \\
\hline 8 & Srondol & 2 & 110.000 & 110.000 & 0 & 80.000 & 5.000 & 152.500 & 305.000 \\
\hline 9 & Tembalang & 3 & 130.000 & 35.000 & 50.000 & 95.000 & 5.000 & 105.000 & 315.000 \\
\hline 10 & Banyumanik & 7 & 240.000 & 85.000 & 75.000 & 232.000 & 30.000 & 94.571 & 662.000 \\
\hline 11 & Candisari & 2 & 160.000 & 100.000 & 80.000 & 85.000 & 0 & 212.500 & 425.000 \\
\hline 12 & Pucang Gading & 4 & 232.000 & 30.000 & 25.000 & 107.000 & 0 & 98.500 & 394.000 \\
\hline 13 & Kaligawe & 1 & 150.000 & 100.000 & 0 & 50.000 & 0 & 300.000 & 300.000 \\
\hline 14 & Brebes & 1 & 300.000 & 100.000 & 0 & 50.000 & 0 & 450.000 & 450.000 \\
\hline 15 & Ungaran & 1 & 10.000 & 10.000 & 0 & 30.000 & 0 & 50.000 & 50.000 \\
\hline 16 & Ambarawa & 8 & 200.000 & 80.000 & 0 & 200.000 & 27.000 & 63.375 & 507.000 \\
\hline 17 & Surakarta & 6 & 355.000 & 50.000 & 0 & 210.000 & 78.000 & 115.500 & 693.000 \\
\hline & Total & & 4.134 .800 & 1.885 .000 & 560.000 & 2.734 .000 & 223.000 & 2.163 .565 & 9.536 .800 \\
\hline & Rata-Rata & & 243.224 & 110.882 & 32.941 & 160.824 & 13.118 & 127.269 & \\
\hline
\end{tabular}

\section{Willingnes to Pay (WTP)}

Keinginan membayar responden terhadap penambahan wahana wisata terdiri dari harga atau tarif keinginan membayar responden yang sesuai, estimasi pengguna, penerimaan dan keuntungan 
bel 6. Keinginan Membayar Responden Terhadap Penambahan Wahana Wisata

\begin{tabular}{lcccr}
\hline \multicolumn{1}{c}{ Jenis Wahana } & $\begin{array}{c}\text { Harga atau } \\
\text { Tarif (Rp) }\end{array}$ & $\begin{array}{c}\text { Estimasi } \\
\text { Pengguna } \\
\text { (Orang) }\end{array}$ & Penerimaan (Rp) & $\begin{array}{c}\text { Keuntungan } \\
\text { (Rp) }\end{array}$ \\
\hline Becak Air & 10.000 & 57.915 & 579.145 .500 & 115.829 .100 \\
Perahu Dayung & 10.000 & 40.406 & 404.055 .000 & 52.527 .150 \\
Mandi Bola & 5.000 & 36.365 & 181.824 .750 & 69.093 .405 \\
Wisata Kuda & 15.000 & 25.590 & 383.852 .250 & 57.577 .838 \\
Banana Boat & 45.000 & 55.221 & 2.484 .938 .250 & 223.644 .443 \\
Wake Board & 100.000 & 33.671 & 3.372 .125 .000 & 920.473 .75 \\
\hline
\end{tabular}

Estimasi pengguna wahana wisata tertinggi adalah becak air. Wahana Wisata becak air merupakan wahana wisata yang mudah digunakan dan cukup digemari untuk penambahan

\section{Nilai Manfaat (Net Benefit)}

Asumsi nilai manfaat (Net Benefit) dipergunakan untuk menghitung estimasi keuntungan usaha yang usaha yang sudah ada dan penambahan wahana wisata di Objek Wisata Waduk Jatibarang.

Tabel 7. Nilai Manfaat (Net Benefit) Jenis Usaha yang Sudah Ada dan Rencana Penambahan Wahana Wisata

\begin{tabular}{|c|c|c|c|c|c|}
\hline \multirow{2}{*}{ Jenis Usaha } & \multicolumn{5}{|c|}{ Tahun } \\
\hline & 1 & 2 & 3 & 4 & 5 \\
\hline Warung Makan & 74.970 .000 & 154.438 .200 & 238.674 .492 & 327.964 .962 & 422.612 .859 \\
\hline Kios Rokok dan & 42.740 .000 & 88.044 .400 & 136.067 .064 & 186.971 .088 & 240.929 .353 \\
\hline Umpan Ikan & & & & & \\
\hline Penjual Souvenir & 10.090 .000 & 20.785 .400 & 32.122 .524 & 44.139 .875 & 56.878 .268 \\
\hline Aneka Jus & 51.360 .000 & 105.801 .600 & 163.509 .696 & 224.680 .278 & 289.521 .094 \\
\hline Speed Boat & 216.490 .000 & 445.969 .400 & 689.217 .564 & 947.060 .618 & 1.220 .374 .255 \\
\hline Perahu Motor & -59.230 .000 & -2.765 .000 & 48.659 .120 & 112.099 .407 & 225.556 .332 \\
\hline Becak Air $(*)$ & 115.829 .100 & 238.607 .946 & 368.753 .523 & 506.707 .834 & 652.939 .404 \\
\hline Perahu Dayung (*) & 52.527 .150 & 108.205 .929 & 114.698 .285 & 121.580 .182 & 128.874 .993 \\
\hline Mandi Bola (*) & 69.093 .405 & 142.332 .414 & 150.872 .359 & 159.924 .701 & 169.520 .183 \\
\hline Wisata Kuda (*) & 57.577 .838 & 118.610 .346 & 125.726 .967 & 133.270 .585 & 141.266 .820 \\
\hline Banana Boat(*) & 223.644 .443 & 460.707 .553 & 488.350 .006 & 517.651 .006 & 548.710 .066 \\
\hline Wake Board $(*)$ & 920.473 .750 & 1.896 .175 .925 & 2.009.946.481 & 2.130 .543 .269 & 2.258 .375 .865 \\
\hline Jumlah & 1.775 .565 .686 & 3.776 .914 .113 & 4.566 .598 .081 & 5.412 .593 .805 & 6.355 .559 .492 \\
\hline
\end{tabular}

Nilai Manfaat Akumulasi 5 Tahun (Rp)

21.887.231.177

Keterangan $(*)$ : Penambahan wahana wisata

Data diatas menunjukkan bahwa usaha yang sudah ada dengan rencana penambahan wahana wisata bisa menaikkan nilai manfaat akumulasi untuk 5 tahun kedepan sebesar Rp. 21.887.231.177,00. Nilai manfaat usaha yang sudah ada jika diakumulasikan sebesar Rp. 6.755.732.849,00. Nilai manfaat rencana penambahan wahana wisata jika diakumulasikan untuk 5 tahun ke depan sebesar Rp. 13.692.352.642,00.

\section{Analisa Laba dan Rugi ( $R / C$ Ratio)}

Pembangunan waduk juga dihitung mengenai biaya laba dan rugi ( $R / C$ Ratio), biaya laba dan rugi tersebut merupakan hasil dari toatal biaya keuntungan, PPn, perijinan, sewa tempat dan penghasilan tiket dibagi dengan biaya pengeluaran. 
Tabel 8.Biaya, Penerimaan dan Keuntungan ( $R / C$ Ratio $)$

\begin{tabular}{|c|c|c|c|c|c|}
\hline Jenis Usaha & $\begin{array}{c}\text { Nilai } \\
\text { Keuntungan } \\
(\mathrm{Rp}) \\
\end{array}$ & $\begin{array}{l}\text { PPn Fasilitas } \\
\text { Wisata (Rp) }\end{array}$ & $\begin{array}{l}\text { Perijinan } \\
\text { (Rp) }\end{array}$ & $\begin{array}{c}\text { Sewa } \\
\text { Tempat } \\
(\mathbf{R p}) \\
\end{array}$ & $\begin{array}{c}\text { Penghasilan Biaya } \\
\text { Tiket Tahun } \\
\text { Sebelumnya(Rp) }\end{array}$ \\
\hline \multirow{2}{*}{$\begin{array}{l}\text { Warung Makan } \\
\text { Kios Rokok dan } \\
\text { Umpan Ikan }\end{array}$} & 74.970 .000 & 13.110 .000 & 5.110 .000 & 5.000 .000 & \multirow[t]{6}{*}{269.372 .000} \\
\hline & 42.740 .000 & 10.370 .000 & 5.110 .000 & 5.000 .000 & \\
\hline Penjual Souvenir & 10.090 .000 & 13.125 .000 & 5.110 .000 & 5.000 .000 & \\
\hline Aneka Jus & 62.160 .000 & 10.470 .000 & 5.110 .000 & 5.000 .000 & \\
\hline Speed Boat & 216.490 .000 & 78.900 .000 & 5.110 .000 & 5.000 .000 & \\
\hline Perahu Motor & 51.360 .000 & 16.670 .000 & 5.110 .000 & 5.000 .000 & \\
\hline Total Biaya Usaha & 395.650 .000 & 142.645.000 & 30.660 .000 & 30.000 .000 & 269.372.000 \\
\hline Total Penerimaan & & & & & 868.327 .000 \\
\hline Pengeluaran & & & & & 655.000 .000 .000 \\
\hline $\begin{array}{l}\text { Pengeluaran } \\
\text { tiap tahun }\end{array}$ & & & & & 13.100.000.000 \\
\hline$R / C$ Ratio & & & & & 0,066 \\
\hline
\end{tabular}

Menurut Tabel diatas nilai $R / C$ Ratio adalah 0,066 sehingga dapat disimpulkan bahwa nilai keuntungan pembangunan waduk tidak impas atau rugi. Nilai keuntungan pembangunan dikatakan layak atau untung apabila lebih dari satu ( $>1$ ), namun jika kurang dari $1(<1)$ pembangunan dikatakan tidak impas.

\section{Kesimpulan}

Kondisi fisik Objek Wisata Waduk Jatibarang dalam kategori baik, sedangkan aksesibilitas dan fasilitas daam kategori tidak baik. Pengembangan Objek Wisata Waduk Jatibarang lebih mengacu pada peningkatan kepuasan dan kenyamanan, selalu menjaga keindahan alam dan opsi penambahan wahana wisata. Wahana wisata yang ada di Objek Wisata Waduk Jatibarang terdiri speed boat dan perahu motor. Potensi yang dapat dikembangkan di Objek Wisata Waduk Jatibarang adalah becak air, perahu dayung, wisata kuda, mandi bola, banana boat dan wake board.. Opsi penambahan wahana wisata menurut responden terdiri dari becak air, perahu dayung, wisata kuda, mandi bola, banana boat dan wake board. Potensi penambahan wisata air yang sesuai dengan estimasi pengguna tertinggi yaitu becak air, Nilai Willingnes to Pay (WTP) adalah sebesar Rp. 10.000,00 dan Nilai Net Benefit adalah sebesar Rp. 115.829.100,00. Perhitungan nilai ekonomi wisata waduk dengan metode Travel Cost Methode (TCM) sebesar Rp. 215.241.445,00/ tahun. Nilai $R / C$ Ratio waduk sebesar 0,066.

\section{UCAPAN TERIMA KASIH}

Penyusunan penelitian ini lancar karena bantuan dari berbagai pihak baik secara langsung maupun tidak, penulis mengucapkan terima kasih kepada:

1. Dr. Ir. Suradi WS, M.S selaku penguji.

2. Bapak Bambang Astoto, Sp.1, selaku Kepala Balai Besar Wilayah Sungai Semarang, Jawa Tengah.

3. Budi Agung Prayoga, S.H dan Suci Wulandari, S.H selaku Kedua orang tua yang selalu memberikan motivasi sehingga skripsi saya cepat selesai

4. Annisa Prayuda, S.KM., Moody Novia Hapsari Putri, S.E dan Azza Shofiya Prayudha selaku saudara kandung dan wanita yang spesial buat saya

5. Keluarga besar Eyang Raden Soemardi Martodarsono dan Eyang Ir. Raden Warsito Pawiro

6. Almarhum Ir. Teguh Aman Purwito yang semasa hidup hingga menjelang ajalnya selalu memotivasi untuk terus melanjutkan pendidikan hingga selesai skripsi

7. Seluruh pihak yang membantu jalannya penelitian ini termasuk keluarga besar mahasiswa Manajemen Sumberdaya Perairan 2012 Universitas Diponegoro. 


\section{DAFTAR PUSTAKA}

BPS Kota Semarang. 2015. Kota Semarang Dalam Angka Tahun 2015.

Common, M dan S. Stagl. 1998. Ecological Economics. Cambridge University Press.

Kusmayadi dan E. Sugiarto. 2000. Metodologi Penelitian dalam Bidang Kepariwisataan. Jakarta. PT. Gramedia Pustaka Utama.

Pramudhito, A. 2010. Aplikasi Biaya Perjalanan (Travel Cost) Pada Wisata Alam Studi Kasus Air Terjun Jumog Kabupaten Karanganyar. Skripsi

Siregar, H 2010. Analisa Nilai Ekonomi dan Tingkat Kunjungan di Objek Wisata Alam Air Terjun Sipiso-Piso Kabupaten Karo. Skripsi

Sugiarto., D. Siagian., L. T Sunaryanto., dan D.S Oetomo. 2001. Teknik Sampling. Jakarta. Penerbit PT.Gramedia Pustaka Utama.

Sulistiyono, N. 2007. Pengantar Ekoturisme: Editor Buku Oding Affandi.

Suwantoro, G. 2002. Dasar-Dasar Pariwisata. Yogyakarta. Penerbit Andi. 